\title{
The Silicon Doctrine
}

\section{Aitor Jimenez}

\author{
The University of Auckland, Auckland, New Zealand, aitor@auckland.ac.nz
}

\begin{abstract}
This article explores and theorises what is here termed the Silicon Doctrine (SD), that is the legal ideology underpinning the libertarian version of the digital economy promoted (among others) by Facebook, Uber, Apple, Amazon, Netflix and Google. The first part of the text explores the Silicon Doctrine's Frankensteinian ideological roots. The second part of the text scrutinises three dimensions of the Silicon Doctrine: 1) data extraction; 2) domination of the informational infrastructure; and 3) labour exploitation. This article examines the social contract proposed by Silicon Valley, evaluating its two-sided role as a disruptive breakout from the twentieth century social model, and as a continuation of the neoliberal shock doctrine.
\end{abstract}

Keywords: digital capitalism, Silicon Valley, Facebook, platforms, Google, law

Acknowledgements: The author wishes to acknowledge the reviewers for their insightful comments and suggestions. Thanks also to Prof. Campbell Jones and Prof. James Oleson for their generosity and support.

\section{Introduction}

In The Shock Doctrine: The Rise of Disaster Capitalism, Naomi Klein (2007) described the legal-political proposal of one of the most influential intellectuals of the neoliberal Chicago school, the economist Milton Friedman (1912-2006). Friedman advocated for the neoliberal regularisation of the financial sector, the privatisation of public companies, and above all, establishing the market as the role model for shaping public policies (Couso 2017). In the prologue of one of his texts he defended the use of political crises to dismantle the protectionist economic structures of the (Southern) American countries (Friedman 2009). What was nothing more than another theory suddenly became mainstream economic policies at the beginning of the 1970s.

The dictatorial regimes imposed by arms in Brazil and Chile followed the economic dictates proposed by Friedman. Although Brazil would soon renounce it, Chile would nevertheless become the benchmark of global neoliberalism. The respected scholar was especially questioned for his intellectual collaboration with Pinochet's bloody regime in Chile. The coup-makers, protected by the United States, took advantage of the political crisis they had caused to promote radical neoliberal economic reforms. The shock doctrine, inspired by Friedman's ideas and put into practice during the Chilean dictatorship, has continued to be used undercover in the so-called war on terror, or as recipes against economic crises (Harvey 2007; Connell and Dados 2014; Monbiot 2016). The Silicon Doctrine was born at the confluence of both phenomena. Its genesis can be traced back to 2001, being the consequence of two major political and economic events: the terrorist attack of $9 / 11$ in New York and Washington (the deadliest in the history of the United States) and the implosion of the technological bubble (or dot-com boom), accelerated by the attacks.

The survivors of the dot-com bubble had to reinvent themselves in a world where the Internet was becoming part of everyday life and, as such, a war scenario. The need to communicate grew along with the need for intelligence agencies to control the new 
networks. The same technologies that enable the Internet as we know it - GPS localisation techniques, cookies, mobile devices, computerised semantic analysis, neural networks, massive data analysis - also supported surveillance and control, both governmental and corporate (Lyon 2003). To develop these new technologies, existing laws were violated. Corporations and governments alike proceeded without consultation: gathering data, experimenting, surveilling; that is, exploiting the grey areas of scarce (or absent) legislation. It became a priority for corporations and governments to advance these technologies, both to generate benefits and to guarantee national security (Richard 2012). But still, until 2007 the absolute implantation of this new technological ecosystem was not guaranteed. Capital, fundamental for driving the project, still did not flow.

Since the outbreak of the 2008 economic crisis and the shaking of traditional markets, global capitals have sought refuge in a new (old) sector, catapulting forward what we now know as digital capitalism (Wonglimpiyarat 2016). The 2008 shock was intelligently used by venture fund executives, who, far from having to assume the legal responsibilities of their corporate crimes (one of the elements at the origin of the 2008 crisis), were recognised as the new heroes of the new economy, first American and then global (Eren 2017). The capital that shook the global economy now flooded Silicon Valley start-ups, for whom, following the influential Declaration of Cyberspace Independence (Perry 1998), the laws of the material word had no legitimacy in cyberspace.

The new shock doctrine is called "disruption" and is celebrated by CEOs and executives, academics, politicians, and consultants like McKinsey (2018) and Deloitte (2019). Tech-publications such as Wired and international organisations such as the OECD (2015) have also recognised disruption as the digital capitalist zeitgeist. A phrase coined by Mark Zuckerberg, Facebook CEO, synthesises the spirit of the disruptive era: "Move fast and break things" (Taplin 2017). The legal consequences of this philosophy have resulted in a permanent violation of human and fundamental rights. Silicon Valley's legal disruptive spirit is a real threat to which the global authorities have begun to pay attention; as reported by the Guardian (Solon 2018), Zuckerberg has had to respond not only to the Senate of his country but also to the European Parliament as a consequence of the irresponsible handling of the data of tens of millions of users. What do we know about the legal and political project behind that profitable and deliberated data misuse? This question raises another, perhaps much more important: What are the legal-political beliefs in which Silicon Valley's version of digital capitalism stands?

This article will answer that question by analysing and interpreting contemporary contributions on and by digital capitalists using a socio-legal approach. With this I aim to offer theoretical grounds from which to reflect Silicon Valley's legal thinking; this may be useful not only in understanding that thinking, but also in building alternatives to it. Section 2 of this article will briefly look at the ideological Frankenstein's monster in which the Silicon Doctrine stands - a monster with a libertarian head, a liberal body and a neoliberal soul - in order to understand Silicon Valley's political stakes. Section 3 explores three of the Silicon Doctrine political pillars: its data extractive model, the monopolist behaviour of digital corporations and the methods those corporations use to exploit their workers and users.

\section{Liberals, Neoliberals and Libertarians}

Standard Silicon Valley is a small strip of territory located in the Santa Clara Valley in California that includes the cities of Mountain View, Palo Alto, San Francisco (not geographically in the Valley but closely related to it), Santa Clara and Sunnyvale. In this 
fraction of Californian territory are concentrated some of the most currently relevant digital economy companies, both in terms of software and hardware (Castells 2014). As reflected by Katz (2015), despite the newness of its media relevance, Silicon Valley has been playing an extraordinary role in technological, financial, educational and management transformations worldwide for almost fifty years. Mazzucato (2015) has described how what she terms an entrepreneurial state (or, in other words, public funding) hides behind the success of the region. As Levine (2018) explains, the Silicon Valley techno-industrial ecosystem prospered in the heat of public funds destined for defence (military) research. Tax-payers' money flowed into private corporations such as Apple or Google, or elite educational institutions like Stanford, creating a unique ecosystem that occupies a privileged place in the development of current (digital) global capitalism (Fisher 2018).

Silicon Valley was, until the first decade of the 21 st century, an almost exclusively technological and economic power. With the rise of companies such as Google and Facebook, Silicon Valley has also found itself to be a political and cultural behemoth, both nationally and internationally. The Silicon Valley platforms not only represent a disruptive channel by which the old powers access new social segments; they are themselves a power demanding an active role in the global arena (Cohen 2018; Solon and Siddiqui 2017). Despite their differences, Silicon Valley corporations are lobbying together in Washington and Brussels, trying to intervene in legislative developments affecting the digital economy, such as copyright or data privacy laws (Cooper and Hirst 2017). The enormous power of these companies has led them to maintain face-to-face diplomacy with nations, as well as to sustain international conflicts with powerful international actors like China or the European Union (Bratton 2016).

While there is no doubt that the weapons industry and speculative investment funds have shaped the character of Silicon Valley, no less relevant have been the cybernetic and utopian thinking of engineers and developers like Engelbart (Katz 2015). Highly disruptive technological products such as online communications, and the interaction between the machine and people through graphic interface, artificial intelligence, virtual reality or the exchange of P2P files, have their theoretical basis in intellectuals whom, like Jaron Lanier, wanted to make a contribution to humanity, or in other words, to "save the world" (2014). This body of utopian developers and intellectuals sought to reaffirm the autonomy of the masses to the detriment of the growing influence of states and private companies, actors on whom they ultimately relied to finance their projects. Therefore, the network formed in Silicon Valley, its companies and its products present a strange and contradictory mixture of radical capitalism and emancipatory potential (Dahlberg 2009).

Silicon Valley's ideological structure is complex, but at least three levels of composition can be identified: a libertarian layer (libertarian as Robert Nozick not as Pyotr Kropotkin); a neoliberal level; and a liberal stratum (liberal as Bernie Sanders not as John Stuart Mill). This heterogeneous composition comes together in a particular and contradictory legal narrative. In the name of freedom, innovation, and the neutrality of the web, Silicon Valley is demanding non-interventionist policies from the State, as well as fighting against current or further privacy laws, or tax regulatory frameworks for the digital economy (Post 2017; Zuboff 2019). At the same time that they claim freedom, the tech companies dominating the network in a quasi-monopoly position impose harsh contractual conditions on their employees and users (Malos et al. 2018; Musk 2018). Companies do not even respect terms of use, as has been probed by the German Federal Cartel Officer in a case where Facebook was found to be combining user data from its different platforms, a practise that went against not only EU and US regulation 
but Facebook's own terms of use. Such is the character of Silicon Valley: freedom for corporations, subjection for consumers.

The three ideological dimensions (libertarian, neoliberal and liberal) have numerous points of contradiction. Progressive liberalism has been embodied in the United States by the Democratic Party. It ranges from the leftist proposals of Senator Bernie Sanders and Elizabeth Warren, to the centrist ones carried out by the ex-secretary of state Hillary Clinton (Noel 2016). Both positions coincide in assuming the need to establish controls and legal mechanisms for capitalism in order to maintain economic and social equilibrium (Hawley 2015). Since the 70s important sectors of the Democratic Party have also embraced the demands of social and civic rights for racial, ethnic, cultural and sexual minorities. Although Silicon Valley has furiously challenged attempts to regulate its capitalist model, it has also embraced and sweetened an individualistic version of multiculturalism in its rhetoric.

Both the neoliberal and the libertarian proposals have tended to find their place in Republican candidacies. Libertarian and neoliberal ideologies defend the hegemony of the market over other social institutions. Their regulatory models are adjusted to this objective, limiting state action as much as possible while encouraging the presence of private actors in all areas, from education, to health, safety, social services, and of course, financial, commercial or productive sectors (Grewal and Purdy 2014). The neoliberal and libertarian ideological discourse makes the individual responsible for structural failures. Under the neoliberal narrative, evolution, progress, and scientific, technical, cultural and economic development depend on a handful of geniuses and makers, without whom humanity would be lost. This mythical story, popularised in the 70s by the novelist Ayn Rand, was taken over by the new neoliberal wave of the 70s and Silicon Valley cyber-utopianism (Freedland 2017). In Rand's narrative (2005) the State, the masses, the crowd, should neither dominate geniuses, nor restrict the work of the creators of worlds. The smaller the intervention of the State, the less submission the individual suffers, the greater the freedom and, with it, the progress.

Although cyber-utopianism and neoliberalism differ diametrically in the rhetoric about minorities, migrants, gender and the environment, they coincide in the recognition of the individual as the historical subject. Silicon Valley and, until very recently, the ultimate representative of neoliberalism, Wall Street, identify the market as the fairer arbitrator of public choices; hence, the State must restrict its activities. Ayn Rand defends an elitism with a strong technocratic flavour, much to the taste of Silicon Valley's techie elite. For Rand, creators, engineers and developers (but not politicians) are among those who should be in charge of the relevant decisions (Berlin 2017). Wall Street agrees with Silicon Valley when considering the need to establish business leadership over political life. It is the market that should guide the polis and not vice versa. After all, isn't money what moves the world? Wall Street and Silicon Valley, often presented as antagonistic forces, intersect in the new economic scenario of CEO-engineers (Cohen 2018).

Silicon Valley believes in a cosmopolitan, technocratic bourgeoisie: a body composed of (intellectually speaking) the best, the fittest, and the most capable; a heroic body that has been entrusted with the task of saving humanity (Solon 2018). Silicon Valley does not believe in homelands, nor in identity groups, nor in inherited communities. The Silicon Doctrine affirms with conviction the new digital social contract: social bonds are created through the affirmation of online subjectivity, joining Facebook groups or forming digital communities. The consumer is at the centre of its faith, a monetised version of the individual, thrilled by the perspective of social climbing in the tech meritocracy ecosystem. As noted by Himanen in his Hacker Ethic (2001), a hacker 
should not be evaluated for his age, sex or ethnicity, but for his ability to hack. That is why in Silicon Valley racism, sexism or any other type of discrimination against social groups is rejected, always through radical individualism (Broockman et al. 2017). The individual must be measured by their talent, not by their appearance. The problem is that, as its critics have pointed out, Silicon Valley has not been settled in an abstract territory where all subjects compete in equal conditions.

California is a fully racialised, stratified, unequal society standing on the shoulders of nearly five hundred years of colonialism (Pitti 2018; Bacon 2018; Levin 2017). The Silicon Doctrine rhetoric asserts that any person with the necessary skill can reach the highest social peaks, in one of the latest restatements of the American dream. However, recent studies reveal that inequality is increasing, the digital divide has not diminished and the social and racial fracture is enlarged. The multicultural narrative of Silicon Valley, curdled with magnanimous gestures through corporate donations, does not confront the structural dimensions of the problem (Walker 2018). In this sense we can affirm that Silicon Valley liberalism grows and prospers in the fertilised field of rightwing neoliberalism, with which it shares the fundamental elements of its ideology: faith in the market, globalism, individualism, technocratism and strong limitation of the State (Wong 2017).

\section{The Pillars of Silicon Doctrine}

\subsection{Data Extraction}

Silicon Valley companies have maintained a frontal opposition to regulations and norms intended to protect users' privacy, as well as to defend intellectual property rights that do not belong to the realm of trade-secret regulations. In the United States (with the exception of California) privacy laws have been articulated in a fragmented manner, sector by sector, which was the preference of the tech industry, who intensely lobbied against any European-like comprehensive regulation (Cohen 2018). Orly Lobel (2016), among others, defends the tech industry position on the basis that old conceptions about privacy should not condition a new and flourishing industry. The bedrock of Platform Capitalism stands on a legal infrastructure that considers private data as a raw resource, res nullius ready to be taken and processed. As Julie Cohen (2017) states, this has allowed the development of an extractive data industry, which barely has to render accounts to users from whom it obtains all kinds of information: from consumer behaviour to the most obscure secrets of users passing through content of messages, mail, or any other type of communication (Cohen 2018).

Behind Alphabet's (and others') techno-utopian rhetoric of development, technological progress, need for openness, and access to information lies an extraordinary will to power in the economic and political spheres. User data can serve to segment markets, as a subject for subsequent marketing campaigns or for the development of new products (Fumagalli et al. 2018; Srnicek 2017a; 2017b; Esteve 2017). This information can be sold to insurance agencies or banks, to possible contractors, or even to intelligence services. That is in the short and mid-term, but platform capitalist companies think in the long-term. Information is not only a resource by itself, but the fuel of machine learning and Al. User data is the necessary supply to develop the technologies that are about to define the coming new industrial revolution, from driverless cars to fully automated smart cities. The information is obtained from multiple extraction points: clicks, browsing or waiting time on the screen, level of interaction, response or mobility. All the information around digital devices, everything that can be processed 
by their means of capturing audio, video, biometrics, geographical position, acquisitions, and navigation can be commercialised (Couldry and Mejias 2019). And that is only the beginning: Google is monetising the management of traffic flux in cities such as Madrid, water consumption, electricity; every aspect from the macro to the micro can be registered, datafied, monetarised. The Silicon Doctrine is the realisation of the Enlightenment, measurement, rationalisation and capitalist efficiency.

New digital capitalism companies have defended access to private data as an essential mechanism to advance in technological development. The massive expropriation of private data has been enunciated in terms of freedom. Any legal restriction on access to private information, including that of a personal nature formerly protected by outdated moral standards of privacy, are now considered obstacles against progress and science. The Silicon Doctrine strongly rejects any regulatory effort aimed to protect private data. It does not do so to claim the emancipatory utopia of the machinic commune in which subjects and machines live in peace without the need for states or corporations, but to affirm the right of digital corporations to govern that 'no-man's land' that are the digital territories; an effective digital colonial government (based on science, progress and reason) that, in the words of Schmidt and Cohen, would redeem humanity from the oppressive presence of states and their bureaucracies (2013).

Many of the arguments adduced by Silicon Valley CEOs to justify their disruptive role in the global economy have to do with their self-identification as creators or makers at the service of humanity. Google, for example, has reiterated that its business mission is "Organize the world's information and make it universally accessible and useful" (Google n.d.). Such a praiseworthy objective would excuse the 'inevitable' slips in the manipulation of private data or market abuse. For these corporations, humanity's most pressing problems, such as inequality or climate change, are not to be solved through structural reforms or the transformation of the economic model, but through a technological transformation driven by them. Morozov (2013) has labelled this techno-determinism "solutionism". In Silicon Valley's parallel universe the interest of conglomerates such as Facebook (Facebook, WhatsApp and Instagram) is to put their users in communication, not to obtain economic benefits; Tinder's is that people find the love they want; Google's is that users have at their disposal the knowledge of humanity. In this narrative there are no shareholders, no bonds, no revenues, no lobbies, and no salaries. When the top managers of big technology companies, like Jeff Bezos or Tim Cook, are queried about the working conditions of their facilities, Internet addiction, or how democracy or the free market are jeopardised by their platforms, they elude the questions. They appeal to the transcendental mission of Silicon Valley's capitalism: how would some sacrifice not be necessary for the greater good? In this way, Bezos (Amazon CEO) has avoided a response in numerous interviews on Amazon's radical anti-union policies; Zuckerberg (Facebook CEO) has denied before the European and US lawmakers his obscure involvement in the massive sale of personal data and the experiments conducted on their users; Chesky (Airbnb CEO) avoids his responsibility with the radical gentrification of the cities where the company he leads is present.

\subsection{Domination of the Informational Infrastructure}

Google has been promoting open source as the instrument to develop its applications by financing large programming events, such as the Summer of Code, where an explicit call was made to hackers to work with the GNU Linux system (Google 2018). It also offers an infinity of free programming courses through digital platforms such as Udacity. Google's rhetoric emphasises that it promotes global digital technological de- 
velopment, improving the services offered and multiplying the offer (since almost literally anyone can contribute to the universe of the apps in the Google Play Store). Thanks to open source, new business, training and development opportunities would arise. Google would certainly get benefits, but in return would be offering (free of charge) tomorrow's means of production, materialising with it the maxim that the company, until recently, wielded: "Don't be evil" (Cassin 2017).

When the European Commission decided to sanction Alphabet (the mother company of Google) with 4.343 million Euros for market abuse of its Android platform, Sundar Pichai, Google's CEO, forcefully contested the decision with a public post at Google's corporate blog (Pichai 2018). His speech makes the defence that Android had been developed in open code; that is, it can be freely manipulated, altered, and reinvented. It is not an operating system based on proprietary code like Microsoft's Windows. Anyone with minimal coding skills can modify it, or create multiple and functional variations of it. Android cannot be a monopoly, claims Pichai; it is rather a free digital ecosystem for mobile devices. Pichai does not deny the lead position of its operating system; however, for the CEO, its success does not correspond to a strategy of violence, intimidation against competitors or predatory prices. On the contrary, according to Alphabet, Android would have opened roads and offered tools, multiplying the possibilities of developers who can now compete globally with strong and ductile work tools. The domain of Android is not such. Its nearly total presence is a liberating force; it offers tools to those who lack them. In his speech, Android's open source breaks the castrating chains of proprietary software (Pichai 2018).

In its plea against the decision of the European Commission, Google failed to mention that the open source of its Android OS is limited to the applications that make the mobile phone a telephone device. The rest of the main apps, such as Maps or the Internet browser, respond to Google proprietary code, i.e. those that today have the highest percentage of smartphone usage. The free software used in Android is subjected to the hegemonic proprietary code of the market, in the hands of the most powerful corporation in the digital economy. Android exemplifies how the techno-libertarian narrative of Silicon Valley conceals a monopolistic reality, explicitly challenged by, among others, the EU institutions (lacobucci and Ducci 2018). The 'open' free code is then configured to affirm the 'closed', to constitute a monopoly. This is not an unexpected or unforeseen result. The monopolistic domain is, in the words of one of the greatest exponents of the Silicon Doctrine, Peter Thiel, desirable both for its efficiency and its profitability, as well as for the supposed benefits for users. Competition, the ideological keystone of market capitalism as we knew it, is, for the founder of Pay-Pal, "for losers" (Thiel 2014). With the use of open source, Google also manages to outsource its innovation services in a process that has been called user-led innovation (Truffer 2003). That is, capitalist companies encourage users to contribute with their ideas and technological developments to the improvement of their products, all without any form of remuneration apart from social recognition in digital forums (or the pride of seeing your product being adopted by the company). Tech companies not only present themselves as corporations that "listen", but also benefit from free labour (Patterson 2016).

\subsection{Exploitation of Labour}

Following a libertarian discourse, the Silicon Doctrine promotes flexibility of contracts and schedules, arguing that they strengthen workers' autonomy and, ultimately, conciliation with their private lives. The flexibilisation of contracts in terms of hiring, labour management and dismissals has been a constant demand of the liberal and libertarian 
sectors, who found in the labour protectionism of social constitutionalism an obstacle to the development of their model. The libertarian narrative asserts that excessive labour regulation prevents quick reactions to economic eventualities. Protective laws slow down fast-hiring processes and make it difficult to implement immediate lay-offs, which in the opinion of the liberal and libertarian sectors compromise quick adaptations to market fluctuations (McArdle et al. 2017). That is why the Silicon Doctrine calls for abandoning the old thinking scheme based on employer-employee duality, replacing it with what has been termed "start-ups of the self" (Hoffman and Casnocha 2013). For Hoffman, co-founder of Linkedln, we the subjects should consider ourselves companies, and thus manage as such; our relationships and personal habits ought to be managed as if they were part of a branding strategy.

To understand the Silicon Valley Doctrine in depth, it is necessary to stop at the work model posed by digital platforms such as Uber or Deliveroo. According to these companies, the worker-entrepreneur owns the means of production, and as such provides services to clients, who access the services through the platform companies. These would be mere facilitators of this exchange, limited to providing the necessary software for these services to be carried out, and charging a certain percentage, either to the client, to the entrepreneur or both. The link, and with it the responsibility between the employer and the platform, begins with the provision of the service and ends with it. Reality, however, is more complex. The digital companies are the ones that determine the conditions of provision of the services, being able to suspend access to their platform in an arbitrary manner. They are the ones who evaluate the independent workers, besides being the only ones able to mediate between them and the clients. They set prices, establish standards and procedures. They determine routes. They control discourse and advertising. For companies, all these signs point not to an employment relationship, but to a contractual relationship between two private companies, regardless of the obvious asymmetry that occurs between, for example, a driver and the digital giant Uber (Rosenblat 2018). The outsourcing of workers' expenses is hidden under the appearance of flexibility of time and contracts. Workers are now accountable for the fiscal, logistical and social security responsibilities that were once corporate duties. The digital precariat maintains a salaried relationship out of sight beneath a false contractual bond of independence (Webster 2016).

Although digital platforms are rabidly arguing for freedom when it comes to fighting for the deregulation of labour markets, their surveillance practices point towards an extraordinarily restrictive interpretation of it. Amazon's distribution centres have been repeatedly identified as spaces of constant violation of the most basic labour rights (Cattero and D'Onofrio 2018). The pressure on workers is extraordinary: frequent accidents, workers who do not even have time to urinate, and constant vigilance and security checks requiring time always at the worker's expense are part of everyday life at Amazon's warehouses. Amazon workers are required to be constantly available: it is irrelevant whether or not they are on the payroll, they must still be willing to accept hourly or daily contracts, with tight pre-warning times. Rejecting these contracts implies penalties that hinder subsequent hiring. That is a regulatory framework of flexibility and precariousness that benefits companies at a high social cost.

Companies like Uber or Deliveroo monitor their workers in real time (Clawson and Clawson 2017). Workers' statistics are evaluated, measured, observed, managed. Amazon's Mechanical Turk, its digital work platform, has managed to advance one more step in surveillance technology, by automating it. Amazon algorithms assess the productivity of workers, deciding who will be hired again and who will not. Amazon is imposing an intensive surveillance regime on its workers at a level never before 
reached. Surveillance strategies include real-time recordings; access to mails, calls, and browsing history; worker-tracking through GPS; extensive data analysis; and metadata obtained through mandatory wristbands (Moore et al. 2018).

Platform capitalist companies have conducted a powerful whitewashing campaign through their resolute rejection of Donald Trump's immigration policies in the United States. Globally they have advocated for greater legal flexibility with workers' mobility, a thesis close to the free-movement-of-people claim. This liberal commitment does not present a conflict with the core of neoliberal thinking. On the one hand, it questions the legitimacy of states to decide on their borders. On the other, it facilitates the provision of a qualified workforce, essential for the growth of technological hubs such as Silicon Valley. The positioning in favour of immigration reform that allows access to a greater volume of foreign labour forces in labour markets is consistent with the defence of the liberalisation of all types of markets and the free movement of goods and capital. As Fuchs (2015) points out, this liberal stance leaves intact the racialised structure of the global division of labour in the digital economy, since it only benefits the labour aristocracy composed of programmers, engineers and developers. The Silicon Doctrine excludes from its social contract the slaves from mineral mines in Africa and Latin America, Chinese and Taiwanese factory workers and Indian and Philippine call centre workers. Silicon Valley companies push to facilitate the importation of highly qualified labour forces, while fighting any kind of protectionist regulation and policies aimed at stopping industrial relocation (Pitti 2018).

To summarise, there are three main pillars of the Silicon Doctrine. The first has to do with the defence of the Doctrine's productive model based on the extraction of data from digital worker-users. Silicon Valley wants free access to data; in this sense Silicon Valley is dedicating enormous political, cultural and economic efforts towards influencing the legislative evolution of everything related to the collection, processing and commercialisation of personal data. The second objective has to do with intellectual production, information and communication flows. Silicon Valley argues that these three areas should be regulated by private agents. The Silicon Doctrine proposes a model of libertarian governance of the network and the flows that take place within it. It criticises rights-based legislation as an obstacle to development, while proposing a legal framework based not on the guaranteeist ontology but on that of the lex mercatoria. The third objective seeks to liberalise labour markets. It is an offensive against the current model of relations of production, which in Western Europe is characterised by the Social Welfare State and Rule of Law. Instead, it proposes a deregulated labour market, characterised by labour relations without collective bargaining, based on radical criteria of temporality, flexibility and finitude. Silicon Valley advocates a libertarian model in terms of hiring, while at the same time imposing an intense digitalised surveillance regime on its workers. In short, the Silicon Valley Doctrine proposes a legal model consistent with its capitalist, neoliberal, neocolonial and libertarian ideological project. Rather than being a novelty, the Silicon Doctrine re-envisions the neoliberal project, adapting it to the digital era.

\section{Conclusion}

As this article has shown, Silicon Valley is not only trying to undermine liberal democracies' legal frameworks, but to replace them. Therefore, Silicon Valley must have a project: but what is that project? What is the set of legal-political beliefs in which Silicon Valley's version of digital capitalism stands? This political and legal strategy has here been termed the Silicon Doctrine. As mentioned earlier, the Silicon Doctrine is an ideological Frankenstein's monster. The libertarian head wants no State control while 
seizing and colonising all available data. Here we have John Locke's old liberal colonial attitude, refashioned for the occasion. The Frankensteinian liberal body tries to hide racial, gender and class discrimination behind a veil of calculated and utterly superficial demands. The monster's body language looks futuristic and progressive, but the will for power and monopolistic control oozes out of its pores. Finally, the neoliberal soul is what makes the Silicon Doctrine so powerful and unsettling. Neoliberalism's disdain for the empire of law, human rights, democracy or even empathy has been manifested in every Big Tech scandal for the last five years, from the blatant Uber and Airbnb violations of labour and housing laws, to Facebook's lies and Google's monopolistic domination. All of the above has been extensively studied and discussed by a plethora of authors; however (to my knowledge) it has never been systematised as a doctrine. As a Marxist legal scholar I found this quite troublesome. It is nearly impossible to propose alternatives to a reality we cannot identify. Now, better or worse, we have a place from which to think of a critical legal doctrine that challenges the Silicon Doctrine.

\section{References}

Aloisi, Antonio. 2018. The Role of European Institutions in Promoting Decent Work in the "Collaborative Economy". In Multidisciplinary Design of Sharing Service, edited by Maurizio Bughlieri, 161-182. Berlin: Springer.

Bacon, David. 2018. Worthless Promises in Silicon Valley. International Union Rights 25 (3): 10-28.

Berlin, Leslie. 2017. Troublemakers: How a Generation of Silicon Valley Upstarts Invented The Future. New York: Simon \& Schuster.

Bilić, Paško. 2018. A Critique of The Political Economy of Algorithms: A Brief History of Google's Technological Rationality. tripleC: Communication, Capitalism \& Critique 16 (1): 315-331.

Bodoni, Stephanie. 2019. Google Clash Over Global Right to be Forgotten Returns to Court. Bloomberg News, 9 January. Accessed 6 March, 2020. https://news.bloomberglaw.com/privacy-and-data-security/google-clash-over-global-right-to-be-forgotten-returnsto-court

Boutcher, Steven A. and Lynette J. Chua. 2018. Introduction: Law, Social Movements, And Mobilization Across Contexts. Law \& Policy 40 (1): 5-9.

Bratton, Benjamin H. 2016. The Stack: On Software And Sovereignty. Cambridge, MA: MIT Press.

Broockman, David, Greg F. Ferenstein and Neil Malhotra. 2017. The Political Behavior of Wealthy Americans: Evidence From Technology Entrepreneurs. Stanford Business School Working Paper, No. 3581.

Buttarelli, Giovanni. 2016. The EU GDPR as a Clarion Call for a New Global Digital Gold Standard. International Data Privacy Law 6 (2): 77-78.

Campbell, Tom. D. 2016. The Legal Theory of Ethical Positivism. London: Routledge.

Cassin, Barbara. 2017. Google Me: One-Click Democracy. New York: Fordham.

Castells, Manuel. 2014. Technopoles of The World. London: Routledge.

Cattero, Bruno and Marta D'Onofrio. 2018. Organizing And Collective Bargaining In The Digitized "Tertiary Factories" of Amazon: A Comparison Between Germany And Italy. In Working in Digital And Smart Organizations, edited by Ales Edoardo, Ylenia Curzi, Tommaso Fabbri, Olga Rymkevich, laccopo Senatori and Giovanni Solinas, 141-164. Basingstoke: Palgrave Macmillan.

Christensen, Clayton M., Michael E. Raynor and Rory McDonald. 2015. What Is Disruptive Innovation? Harvard Business Review 93 (12): 44-53.

Clawson, Dan and Mary A. Clawson. 2017. IT Is Watching: Workplace Surveillance and Worker Resistance. New Labor Forum 26 (2): 62-69.

Cohen, Julie. E. 2019. Turning Privacy Inside Out. Theoretical Inquiries in Law 20 (1): 1-31. 
Cohen, Julie. E. 2017. Law for the Platform Economy. UC Davis Law Review 51 (1): 133205.

Cohen, Noam. 2018. The Know-It-Alls: The Rise of Silicon Valley as a Political Powerhouse And Social Wrecking Ball. London: Oneworld.

Connell, Raewyn and Nour Dados. 2014. Where in The World Does Neoliberalism Come From? Theory And Society 43 (2): 117-138.

Cooper, Harry and Nicholas Hirst. 2017. Silicon Valley Tech Lobbyists Swarm Brussels. Politico, 4 May. Accessed 6 March, 2020. https://www.politico.eu/article/silicon-valley-techlobbyists-swarm-brussels/

Couldry, Nick and Ulises Mejias. 2019. Data Colonialism: Rethinking Big Data's Relation to the Contemporary Subject. Television \& New Media 20 (4): 336-349.

Couso, Javier. 2017. Constructing "Privatopia": The Role of Constitutional Law in Chile's Radical Neoliberal Experiment. In The Politics of Legality in a Neoliberal Age, edited by Ben Golder and Daniel Mcloughlin, 84-96. London: Routledge.

Dahlberg, Lilcon. 2009. Libertarian Cyber-Utopianism And Global Digital Networks. In Globalization and Utopia, edited by Patrick Hayden and El-Ojeili Chamsy, 176-189. London: Palgrave Macmillan.

De Graaf, Gerard. 2017. Digital Economy Development in Spain. ICE: Revista De Economía 897: $129-140$.

Deloitte Touche Tohmatsu Limited. 2019. On Disruption. Deloitte Perspectives [blog]. Accessed March 1, 2020. https://www2.deloitte.com/us/en/pages/risk/articles/deloitte-on-disruption.html

Eren, Colleen P. 2017. Bernie Madoff And The Crisis: The Public Trial of Capitalism. Redwood City: Stanford University Press.

Esteve, Asuncion. 2017. The Business of Personal Data: Google, Facebook, And Privacy Issues in the EU and the USA. International Data Privacy Law 7 (1): 36-47.

Ferguson, Andrew. G. 2017. The Rise of Big Data Policing: Surveillance, Race, And The Future of Law Enforcement. New York: New York University Press.

Finn, Ed. 2017. What Algorithms Want: Imagination in the Age of Computing. Cambridge, MA: MIT Press.

Fisher, Adam. 2018. Valley of Genius: The Uncensored History of Silicon Valley: As Told by The Hackers, Founders, and Freaks Who Made It Boom. New York: Hachette.

Freedland, Jonathan. 2017. The New Age of Ayn Rand: How She Won Over Trump And Silicon Valley. The Guardian, 10 April. Accessed 7 March, 2020. https://www.theguardian.com/books/2017/apr/10/new-age-ayn-rand-conquered-trump-white-house-silicon-valley

Friedman, Milton. 2009. Capitalism and Freedom. Chicago: University of Chicago Press.

Fuchs, Christian. 2016. Facebook. In Global Media Giants, edited by Benjamin Birkinbine, Rodrigo Gomez and Janet Wasko, 442-458. New York: Routledge.

Fuchs, Christian. 2015. Culture and Economy In The Age of Social Media. New York: Routledge.

Fuchs, Christian. 2014. Digital Labour and Karl Marx. New York: Routledge.

Fuchs, Christian. 2011. A Contribution to The Critique of The Political Economy of Google. Fast Capitalism 8 (1): 1-24.

Fumagalli, Andrea, Stefano Lucarelli, Elena Musolino and Giulia Rocchi. 2018. Digital Labour in the Platform Economy: The Case of Facebook. Sustainability 10 (6): 1-16.

Gil, Javier and Jorge Sequera. 2018. The Expansion of the Tourist City and New Resistances: The Case of Airbnb in Madrid. Empiria 41 (1): 15-32.

Google. 2018. Google Summer of Code [website]. Accessed 7 March, 2020. https://summerofcode.withgoogle.com/

Google. n.d. About [website]. Accessed 10 March, 2020. https://about.google/

Grewal, David. S. and Jedidiah Purdy. 2014. Introduction: Law and Neoliberalism. Law \& Contemporary Problems 77 (4): 1-24. 
Hart, Herbert. L. A. 2017. Positivism and the Separation of Law and Morals. In Law And Morality, edited by Kenneth Einar, 63-99. New York: Routledge.

Harvey, David. 2007. Neoliberalism as Creative Destruction. The Annals of The American Academy of Political and Social Science 610 (1): 21-44.

Hawley, Ellis. W. 2015. The New Deal and The Problem of Monopoly. Princeton: Princeton University Press.

Himanen, Pekka. 2001. The Hacker Ethic. New York: Random House.

Hobbs, Mitchell, Stephen Owen and Livia Gerber. 2017. Liquid Love? Dating Apps, Sex, Relationships and the Digital Transformation of Intimacy. Journal of Sociology 53 (2): 271284.

Hoffman, Reid and Ben Casnocha. 2013. The Start-Up of You: Adapt to The Future, Invest In Yourself, and Transform Your Career. New York: Random House.

Hoskyns, Catherine. 2018. Democratizing the European Union: Issues for the Twenty-First Century. London: Routledge.

Houser, Kimberly and W. Gregory Voss. 2018. GDPR: The End of Google and Facebook or a New Paradigm in Data Privacy? Richmond Journal of Law and Technology 25 (1): 1109.

Hyde, Alan. 2015. Working in Silicon Valley: Economic and Legal Analysis of a High-Velocity Labor Market. New York: Routledge.

lacobucci, Edward and Francesco Ducci. 2019. The Google Search Case in Europe: Tying and the Single Monopoly Profit Theorem in Two-Sided Markets. European Journal of Law and Economics 47 (1): 15-42.

Janeway, William. H. 2018. Doing Capitalism in the Innovation Economy: Reconfiguring the Three-Player Game between Markets, Speculators and the State. Cambridge: Cambridge University Press.

Katz, Barry. 2015. Make It New: The History of Silicon Valley Design. Cambridge, MA: MIT Press.

Klein, Naomi. 2007. The Shock Doctrine: The Rise of Disaster Capitalism. Toronto: Random House.

Lanier, Jaron. 2014. Who Owns the Future? New York: Simon \& Schuster.

Laurens, Sylvain. 2017. Lobbyists and Bureaucrats in Brussels: Capitalism's Brokers. London: Routledge.

Lazzarato, Mauricio. 2014. Signs and Machines: Capitalism And The Production of Subjectivity. Los Angeles: Semiotext(e)

Levin, Sam. 2017. Black and Latino Representation in Silicon Valley Has Declined, Study Shows. The Guardian, 3 October. Accessed 7 March 2020. https://www.theguardian.com/technology/2017/oct/03/silicon-valley-diversity-black-latino-women-decline-study

Levine, Yasha. 2018. Surveillance Valley: The Secret Military History of The Internet. New York: Public Affairs.

Lobel, Orly. 2016. The Law of The Platform. Minnesota Law Review 101 (1): 87-161.

Lucas, Manuel. J. 2017. Problemática Jurídica De La Economía Colaborativa: Especial Referencia A La Fiscalidad De Las Plataformas. Anuario De La Facultad De Derecho 10: 131172.

Luhmann, Niklas. 2004. Law as a Social System. Oxford: Oxford University Press.

Lyon, David. 2003. Surveillance after September 11. Cambridge: Polity.

Mackey, John and Rajendra Sisodia, 2013. Conscious Capitalism: Liberating The Heroic Spirit of Business. Cambridge, MA: Harvard Business Review Press.

Malone, Michael. S. 2002. The Valley of Heart's Delight: A Silicon Valley Notebook 19632001. Hoboken: Wiley.

Malos, Stan, Gretchen V. Lester and Meghna Virick. 2018. Uber Drivers and Employment Status in the Gig Economy: Should Corporate Social Responsibility Tip the Scales? Employee Responsibilities and Rights Journal 30 (4): 239-251. 
Martini, J. Domenic. 2017. International Regulatory Entrepreneurship: Uber's Battle With Regulators In France. San Diego International Law Journal 19 (1): 127-160.

Marx, Karl. 1993. Grundrisse. London: Penguin.

Mazzucato, Mariana. 2015. The Entrepreneurial State: Debunking Public vs. Private Sector Myths [Revised Edition]. Philadelphia: Public Affairs.

McArdle, Louise, Richard Saundry and Pete Thomas. 2017. Special Issue on the Enactment of Neoliberalism in the Workplace: The Degradation of the Employment Relationship. Competition \& Change 21 (3): 247-249.

McKinsey. 2018. Digital Disruption. McKinsey Insights [blog post]. Accessed 7 March, 2020. https://www.mckinsey.com/featured-insights/digital-disruption

Merchant, Brian. 2015. Fully Automated Luxury Communism. The Guardian, 18 March. Accessed 7 March, 2020. https://www.theguardian.com/sustainable-business/2015/mar/18/fully-automated-luxury-communism-robots-employment

Monbiot, George. 2016. Neoliberalism: The Ideology at the Root of All Our Problems. The Guardian, 15 April. https://www.theguardian.com/books/2016/apr/15/neoliberalism-ideology-problem-george-monbiot

Mohri, Mehriar, Afshin Rostamizadeh and Ameet Talwalkar. 2018. Foundations of Machine Learning. Cambridge, MA: MIT Press.

Moore, Martian and Damian Tambini, eds. 2018. Digital Dominance: The Power of Google, Amazon, Facebook, and Apple. Oxford: Oxford University Press.

Moore, Phoebe V., Martin Upchurch and Xanthe Whittaker. 2018. Humans and Machines at Work. Basingstoke: Palgrave Mcmillan.

Moravcsik, Andrew. 2017. Europe Is Still A Superpower. Foreign Policy, 14 April. Accessed 7 March, 2020. https://Foreignpolicy.Com/2017/04/13/Europe-ls-Still-A-Superpower/

Morozov, Evgeny. 2013. To Save Everything, Click Here: The Folly of Technological Solutionism. New York: Public Affairs.

Moulier-Boutang, Yann. 2016. Du Capitalisme Fordiste Au Nouveau Capitalisme: Les Filets Du Capitalisme Cognitif, Pour Comprendre La Guerre Des Codes. In Capitalismo Cognitivo Y Economía Social Del Conocimiento: La Lucha Por El Código, edited by Francisco Sierra, 15-57. Quito: Ciespal.

Musk, Elon. 2018. Elon Musk: We Must Colonise Mars to Preserve Our Species in a Third World War [video]. The Guardian, 12 March. Accessed 7 March, 2020. https://www.theguardian.com/technology/video/2018/mar/12/elon-musk-we-must-colonisemars-to-preserve-our-species-after-a-third-world-war-video

Noel, Hans. 2016. Ideological Factions in The Republican and Democratic Parties. The ANNALS of the American Academy of Political And Social Science 667 (1): 166-188.

OECD. 2015. Disruptive Innovations and Their Effect on Competition [webpage]. Accessed 7 March, 2020. https://www.oecd.org/daf/competition/disruptive-innovations-and-competition.htm

Pascual, Gabriel. 2015. La Regulación De La Economía Colaborativa: El Caso Uber Contra El Taxi. Ceflegal. Revista Práctica De Derecho 175-176: 61-104.

Pasquale, Frank. 2016. Two Narratives of Platform Capitalism. Yale Law \& Policy Review 35 (1): 309-320.

Pasquinelli, Mateo. 2009. Google's Pagerank Algorithm: A Diagram of Cognitive Capitalism and the Rentier of The Common Intellect. In Deep Search: The Politics of Search Beyond Google, edited by Konrad Becker and Felix Stalder, 152-163. Innsbruck: Studienverlag.

Patterson, David. 2016. An Interview With Stanford University President John Hennessy. Communications of the ACM 59 (3): 40-45.

Perry, Stephen. R. 1998. Hart's Methodological Positivism. Legal Theory 4 (4): 427-467.

Pichai, Sundar. 2018. Android Has Created More Choice, Not Less. Google Blog, 18 July. Accessed 7 March, 2020. https://www.blog.google/around-the-globe/google-europe/android-has-created-more-choice-not-less/ 
Pitti, Stephen. J. 2018. The Devil in Silicon Valley: Northern California, Race, And Mexican Americans. Princeton: Princeton University Press.

Popper, Ben. 2017. Google Announces Over 2 Billion Monthly Active Devices on Android. The Verge, 17 May. Accessed 7 March, 2020. https://www.theverge.com/2017/5/17/15654454/android-reaches-2-billion-monthly-active-users

Post, Robert. C. 2017. Data Privacy and Dignitary Privacy: Google Spain, The Right to be Forgotten, and the Construction of the Public Sphere. Duke Law Journal 67 (5): 981-1072.

Rand, Ayn. 2005. Atlas Shrugged. London: Penguin.

Richards, Neil M. 2012. The Dangers of Surveillance. Harvard Law Review 126 (7): 19341965.

Rosenblat, Alex. 2018. Uberland: How Algorithms Are Rewriting The Rules of Work. Berkeley: University of California Press.

Rouvroy, Antoinette and Bernard Stiegler. 2016. The Digital Regime of Truth: From the Algorithmic Governmentality to a New Rule of Law. La Deleuziana: Online Journal of Philosophy 3 (1): 6-29.

Savolainen, Javier. 2018. Hotel Industry Competitive Responses Against Airbnb: A Case Study of Hotels Vs. Airbnb in Helsinki. MA Thesis. Espoo: Aalto University.

Scheiber, Noam. 2018. Gig Economy Business Model Dealt a Blow in California Ruling. The New York Times, 30 April. Accessed 7 March, 2020. https://www.nytimes.com/2018/04/30/business/economy/gig-economy-ruling.html

Schmidt, Eric and Jared Cohen. 2013. The New Digital Age: Reshaping the Future of People, Nations and Business. London: Hachette.

Scholz, Trebor. 2017. Uberworked and Underpaid: How Workers are Disrupting the Digital Economy. Hoboken: Wiley.

Scholz, Trebor, ed. 2012. Digital Labor: The Internet as Playground And Factory. New York: Routledge.

Scholz, Trebor and Nathan Schneider, eds. 2017. Ours to Hack and to Own: The Rise of Platform Cooperativism. A New Vision for the Future of Work And A Fairer Internet. New York: OR Books.

Scott, Mark and Nicholas Hirst. 2018. Google's Academic Links Under Scrutiny. Politico, 16 March. Accessed 7 March, 2020. https://www.politico.eu/article/google-campaign-for-accountability-lobbying-humboldt-ceps-astroturfing-oracle/

Sieder, Rachel and Anna Barrera. 2017. Women and Legal Pluralism: Lessons from Indigenous Governance Systems in the Andes. Journal of Latin American Studies 49 (3): 633658.

Signes, Adrián. T. 2017. Los Falsos Autónomos en el Contrato de Franquicia: La Importancia de la prestación de Servicios Bajo Una Marca Ajena Como Indicio de Laboralidad en el Contrato de Trabajo. Revista de Derecho Social 77 (1): 105-124.

Slee, Tom. 2017. What's Yours is Mine: Against the Sharing Economy. New York: OR Books.

Solon, Olivia. 2018. How Europe's 'Breakthrough' Privacy Law Takes on Facebook And Google. The Guardian, 19 April. Accessed 7 March, 2020. https://www.theguardian.com/technology/2018/apr/19/gdpr-facebook-google-amazon-data-privacy-regulation

Solon, Olivia and Sabrina Siddiqui. 2017. Forget Wall Street - Silicon Valley is The New Political Power in Washington. The Guardian, 3 September. Accessed 7 March, 2020. https://www.theguardian.com/technology/2017/sep/03/silicon-valley-politics-lobbyingwashington

Spencer, David A. 2018. Fear and Hope in an Age of Mass Automation: Debating the Future of Work. New Technology, Work And Employment 33 (1): 1-12.

Srnicek, Nick. 2017a. Platform Capitalism. Hoboken: Wiley.

Srnicek, Nick. 2017b. The Challenges of Platform Capitalism: Understanding the Logic of a New Business Model. Juncture 23 (4): 254-257. 
Taplin, Jonathan. 2017. Move Fast and Break Things: How Facebook, Google, and Amazon Have Cornered Culture and What It Means for All of Us. New York: Macmillan.

Thiel, Peter. 2014. Competition is For Losers. The Wall Street Journal, 12 September.

Truffer, Bernhard. 2003. User-Led Innovation Processes: The Development of Professional Car Sharing by Environmentally Concerned Citizens. Innovation: The European Journal of Social Science Research 16 (2): 139-154.

Walker, Richard A. 2018. Pictures of a Gone City: Tech and the Dark Side of Prosperity in The San Francisco Bay Area. Oakland: PM.

Webster, Juliet. 2016. Microworkers of the Gig Economy: Separate And Precarious. New Labor Forum 25 (3): 56-64.

Wingfield, Nick. 2017. Miscue Calls Attention to Amazon's Dominance in Cloud Computing. The New York Times, 12 March. Accessed 7 March, 2020. https://www.nytimes.com/2017/03/12/business/amazon-web-services-outage-cloud-computing-technology.html

Wong, Julie. 2017. Meet the Right-Wing Power Players Lurking Beneath Silicon Valley's Liberal Façade. The Guardian, 10 February. Accessed 7 March, 2020. https://www.theguardian.com/technology/2017/feb/10/silicon-valley-right-wing-donald-trump-peter-thiel

Wonglimpiyarat, Jarunee. 2016. Exploring Strategic Venture Capital Financing with Silicon Valley Style. Technological Forecasting And Social Change 102 (1): 80-89.

Zuboff, Shoshana. 2019. The Age of Surveillance Capitalism: The Fight for a Human Future at the New Frontier of Power. New York: Public Affairs.

Zuboff, Shoshana. 2015. Big Other: Surveillance Capitalism and The Prospects of an Information Civilization. Journal of Information Technology 30 (1): 75-89.

\section{About the Author}

\section{Aitor Jimenez}

Aitor Jimenez is an academic, lawyer, and activist. He is a visiting research scholar from Auckland University at the Universidad Complutense de Madrid. Aitor Jimenez is currently organising several courses on digital capitalism among other things. His current research looks at digital capitalism's regulatory framework. His work is focused on the question of how we can communalise/socialise/nationalise the digital commons. 